\title{
The Social Network of Urban Agriculture
}

\author{
Mpigi Gbenekanu Ledornu \\ Development Planning Unit \\ University College London \\ g.mpigi@gmail.com \\ Collins Wizor \\ Department of Geography and Environmental management \\ University of Port Harcourt. \\ collins.wizor@uniport.edu.ng
}

\begin{abstract}
This paper explains how poor urban households in Port Harcourt City, Nigeria, engage with urban agricultural production practices in order to improve their conditions. It shows that this engagement is socially mediated by a primary desire for households' food security. An important feature of the assertions made about conventional approaches to economic development relating to Nigeria was the assumption that this would bring about more jobs and employment. They contrasted rural with urban areas and agriculture with industries but because they were not well planned for in terms of policies, they all failed in the early 1980s. Urban agriculture then act as a shock absorber to cushion the effect of these bad policies on urban households. One of such policies is the Land Use Act 1978 which forced urban households engaging with UA to abandon their urban land with little or no compensation. This has continued during and after the structural adjustments programmes till date and poverty reduction policies are yet to incorporate urban agriculture as an urban livelihood strategy. This paper reviewed the phases of development in Nigeria, made case for urban agriculture as part of urban production system and suggested that urban agriculture should be defined in context to its features and the particular city hosting it.
\end{abstract}

KEYWORDS: Urban agriculture, livelihood, diversification, informality, poverty, land tenure, food security, PHC, Nigeria.

\section{Introduction}

Growing urban poverty goes hand in hand with food insecurity and malnutrition in the urban areas. Both in the South and in the North, especially in the bigger cities, the urban poor find it increasingly difficult to access food. Food composes a substantial part of urban household expenditures (60-70\%) and lack of cash income translates more directly into food shortages and malnutrition in the city context. Urban agriculture has the tendency to bridge these gaps between poor urban households and food security (Dubbeling, 2006)

This paper clarifies the concept of urban agriculture used in this research and locates it in a series of debates about what urban agriculture is, and how it is linked to urban poverty and urban land use planning. "Urban agriculture" is clearly a compound term, 
economic relations. And, within each one of these, there are different levels, scales, stages and intensities of phenomena. It is therefore necessary to establish a starting point - a working definition of urban agriculture - in order to proceed with the position of this paper. Although the broader research has at its core urban agriculture, poverty and informality, it is clarifying what UA is in this paper that is at the core of this paper.

It begin by identifying the key characteristics of urban agriculture that differentiate it from agricultural activities that are associated with either rural small-scale or peasant farming and commercialised large-scale farming in rural areas. It is important to identify these as they interact with factors in sociality of informality framework and through this interaction, this paper is able to ultimately draw conclusions about how understandings of urban agriculture could change. With a working definition of urban agriculture, the paper consider the scholarly debates about urban agriculture, noting how understandings have changed over the last 30 years.

It then considers how urban agriculture is related to urban poverty and urban land use planning in the literature. This provides a context for this research which locates urban agriculture in relation to urban poverty and land use planning.

\section{Implications Around Concepts in the Research}

This paper emanates from a research which addresses issues that shape livelihoods of the urban poor involved in urban agriculture in the city of Port Harcourt Nigeria. In the international literature, the concept of UA has changed in important ways (Mougeot, 2000; Shillington, 2013). It is important to reflect on these changes because they have changed the ways in which policy makers have responded to its existence in cities of the world.

For instance, economic changes and liberalisation were expected to come with the state of economic structures or enactments that can be renowned from others ${ }^{1}$. An important feature of the assertions made above relating to Nigeria was the assumption that this would bring about more jobs and employment. They contrasted rural with

\footnotetext{
${ }^{1}$ In Nigeria, different government at the centre set up its economic team to formulate and implement its economic promises to the people. They come with promises to improve on what others have been doing but they do not always yield desired results.
} 
urban areas and agriculture with industries but because they were not well planned for in terms of policies, they all failed in the early 1980s. This idea was bolstered by the, not always obviously stated, idea that adaptation and division of labour are fundamental ingredients for the transformation of the economy. A prime example was the co-production model practice in the educational system in Nigeria in the early 1980s; in this practice, the Parent Teachers' Association (PTA) worked together with schools' managements to deliver quality education to primary school pupils.

Secondly, UA as an activity engaged with by mostly the urban poor households is a consequence and response to poverty. This is because people turn to it as a result of poverty. This activity requires little or none formal education to practice. Response to poverty because poor people that have access to land, labour relations and or financing turn to it and improve their economic situations, therefore in $\mathrm{PHC}$ people start, diversify within and out of UA to make ends meet. Reasons why people diversify out include; loss of access to land, migration, health and other assets that are needed for sustaining this practice.

\section{Features of Urban Agriculture in Port Harcourt City.}

Several researchers have tried to use criteria such as closeness to the city centres, inclusion in the city master plan and type of products grown to distinguish between UA and rural agriculture. They argue that the variables listed above distinguish UA from rural agriculture because it is practiced around and within the cities, formally recognised and its output delivered same day to end users (De Zeeuw, Van Veenhuizen, \& Dubbeling, 2011; L. J. A. Mougeot, 2006). After reviewing related literature on UA, L. J. M. Mougeot, (2000) concludes that none of the criteria stated above is the most distinguished criteria of UA but what is its relations to the city. In his view, the fact that it is an integral part of the urban economics, social and ecological system makes UA unique compared to rural or mechanised agriculture. He concludes that although some forms of UA are based on temporal use of vacant lands, UA in general, is a permanent feature of many cities in the developed and developing countries. 
In the view of this paper, Mougeot's, (2000) point of characterising urban agriculture adequately align with how it should be understood. The interaction of UA with the urban dynamics, the city economy and making use of material and resources found within the particular city makes it unique compared to other forms of agriculture. Therefore, the interaction between UA and the city's economy, social networks of the city and its usage of the natural urban resources as inputs make it different from other forms of agriculture.

Other scholars (Shillington, 2013 and Zasada, 2011) define UA in general terms and rarely use the findings of their research to refine the concept of their UA definition, refine typologies or analyse how this concept is related to urban development (L. J. M. Mougeot, 2000). On their part, Drechsel and Dongus (2010) point out that the selection of a particular criterion is often based on the author's discipline or on the use of the study. My research is aware that one of the major reasons for such diverse definitions, research and typologies of UA is because it is relatively new and its study aims are diverse too (Drechsel \& Dongus, 2010; Scott et al., 2010). Another important fact is the diversity in farming conditions ${ }^{2}$ within the urban settings and the high dynamism in UA which makes it attractive and easy to characterise (La Rosa, Barbarossa, Privitera, \& Martinico, 2014).

This research arrived at the working definition of UA ( $\sec 2.3)$ by going through three phases of definitions of UA as explained in ( $\sec 2.3 .1,2.3 .2$ and 2.3.3) of this chapter. In my view, all of those understanding of $U A$ as explained in this chapter, acknowledged the fact that UA is locally based, and having a clear value chain ${ }^{3}$. It is different from rural agriculture because it is based in the city and on its edges and considers its features in relation to the economy of such city and the built environment. The seven distinguishing factors that this paper draw from the literature and discuss below includes: ease of entry and exit; land tenure; financing; labour relations; proximity to market; storage and preservation; and relationship to the environment being mediated by the built environment.

\footnotetext{
${ }^{2} \mathrm{How}$ those practicing urban agriculture adjust their practices to accommodate other urban space users. ${ }^{3}$ The value chain associated with urban agriculture in Port Harcourt City would be another way to analyse different aspect of the phenomenon.
} 
This paper concludes that the three phases of defining urban agriculture have shortcomings, which came from lack of engagement of the difference made by the city to shape UA practices. It is evident that people turn to UA because of poverty, and also UA that started as a coping strategy is now called industry and business (ILO, 2013). This means that there is more to it than people assume, including what it contributes to the city economy and the urban households engaging with it. Therefore, this paper is suggesting that to understand UA as a livelihood strategy for the poor urban households in PHC Nigeria, it should be characterised with the seven features below.

(i) Entry and Exit Points: Urban agriculture has for decades (1980s-date) served as a vital input in the livelihood strategies of urban households in developing countries (Knoblauch, 2012). As a response to the economic crises exacerbated by the structural adjustment programmes, and increasing urbanisation (rural-urban migration without adequate development plans for the new urban population). UA has expanded rapidly within the last 30 years, the acceptance and incorporation into development plans of cities has made it a component of urban development strategies for the global south (Yves Cabannes \& Raposo, 2013). Most important to proponents of UA, is the entry and exit points, it is an activity seen by those engaging with it as an add-on to what some urban households are doing pending when other options become available and exit it because of it lack of social security (Ellis \& Allison, 2001). This activity often requires little or no form of formal education to enter but builds on a high indigenous knowledge of UA practices and similarly, and can be left relatively easily without significant losses in investments.

At the point that urban households are faced with situations that prompt re-evaluation of their economic activities, either into or out of UA, there is always consideration of factors that drive this process. Food security is one of the prime motivations why urban households diversify their livelihood strategies into and within the informal economy. Every household's head tries the best they can to provide for the household through different means and in PHC, working through informality is a common way to achieve that desire. Households in informality in Port Harcourt City make use of their informal relations, institutions and networks to access livelihood supports they need to achieve food security. 
(ii) Land Tenure: Land availability and access is a severe problem facing food production in $\mathrm{PHC}$ today. It is evident that UA provides urban farmers with important employment and food security opportunities that would not otherwise be available (Ezedinma \& Chukuezi, 1999; K. Lynch, Binns, \& Olofin, 2001). Crop production on urban open spaces appears as a way of addressing hunger and such spaces can be highly productive and a profitable phenomenon. However, it is often constrained by tenure insecurity and non-agricultural land demands such as housing and recreational space (Drechsel \& Dongus, 2010). Despite these constraints, the phenomenon of UA appears persistent and resilient (households still hold unto the practices) to its changing environment, although urban farmers might have to shift to other sites when their plots are needed for building purposes. Providing secured land tenure to UA workers tends to improve their aspiration to engage with urban agriculture as a livelihood means.

Secured land tenure is a serious concern when dealing with the issue of provision of food to the rapidly growing urban populations in Port Harcourt City, Nigeria. For instance, though there is a Land Use Decree 1978 that deals with how land should be administered, it is still evident till today that with the exception of Abuja which is the federal capital territory, in other states, the majority of lands are still administered through their traditional landownership ${ }^{4}$ (Awotide, Kehinde, \& Agbola, 2010; Guyer et al., 2007). The owners register such land to avoid issues of land racketeering and as such the landholding families are prevented from reselling such land to different people. These scenarios (different members of a family selling the same land to different members of the public) have led to more ambiguity in the urban land market of PHC.

Although much emphasis has been given in recent years to the growing of basic foodstuffs in urban and peri-urban areas, enhanced by secure land tenure (Guyer et al., 2007; McLees, 2011; Obeng-Odoom, 2013). There are still concerns about its impact on the environment and people (K. Lynch et al., 2001; L. J. M. Mougeot, 2000). Later in this thesis when the composition of the urban fabric of the city of Port Harcourt will be explained, it will become clearer why this policy change will become a

${ }^{4}$ This is where private landowners sell their lands to individuals and such person will take the agreement they signed to the land registry and formally register the land to formalise it. 
sustainable urban livelihood strategy for the urban households. It will do this through the provision of access and availability of food to households, employment and reduction of poverty.

Therefore, the difference made by land tenure to urban agriculture which is different from rural and commercial agriculture can be seen partly from land availability and access. Although land is scarcely available for agricultural purposes in cities such as $\mathrm{PHC}$, people that owns land that not developed grant access to urban agriculture workers as a form of security. Land racketeering is more rampant in the urban areas than the rural areas, and as such when a piece of land is left vacant, it creates room for such. Situations like this gives land access to urban agriculture workers but the major difference in it is, while rural and commercial agriculture farmers might have permanent access and secured tenure, urban agriculture workers usually have insecure tenure and temporal access to land in the cities.

(iii) Financing: It is defined here as a complex and dynamic combination of resource mobilisation, both monetary and non-monetary, with savings and subsidies ( $\mathrm{Y}$. Cabannes, 2012). This research chose this broad definition of financing to include all informal processes that urban households seek support from in UA. For most smallholder urban farmers, the lack of access to financing is a major bottleneck in their capacity to maintain and expand their activities, and more generally in the potential for scaling up affordable food production in cities (Egbuna, 2010). Research undertaken by local teams in 17 cities of different sizes in Latin America, Asia and Africa show that urban farmers are financing their activities (production-marketing), essentially with their own resources, but are willing to accept states involvement in financing through provision of short term loans from the micro-finance (Tanner \& Mitchell, 2009).

From the fieldwork experience, one of the ways UA is self-financing is through the labour relation, in the case of shared labour an urban famer can take shared labour to another person's farm and collect money in return. While rural and commercial agriculture farmers might be able to obtain credit facilities because of the bigger sizes of plots which in-turn can be used as collateral, the urban farmers do not have such privilege. Most of them do not have secure land tenure and those that have might be insignificant. 
The urban economy is more cash based than the rural economy in which rural agriculture is placed and, also differs in financing scale with commercial agriculture. To finance activities in urban agriculture, it requires more finance than that of the rural agriculture. The fact that most of the UA workers operate on a small scale means it is difficult to attract the kind of financing that is associated with commercial agriculture. Understanding these differences associated with urban agriculture, helps during its definitions to differentiate it from rural and commercial agriculture.

(iv) Labour Relations: The labour relation in UA is one of motivations urban households consider during the entry and exit point in their engagement with urban agriculture. It becomes so vital to this study because every link in the web of the UA activities has labour considerations in it. In most cases while a male member of the household goes to harvest, the female member goes to sell the produce in the market (Midmore \& Jansen, 2003; Zasada, 2011). From the production phase of UA to recycling, labour is required. So, understanding the labour relations in UA of Port Harcourt will help this research bridge this gap between UA and policy in Port Harcourt city. UA is viewed as a family based activity by my research and most families and households engaging with UA depend largely on the use of family/household labour in the global south (Otsuka, Quisumbing, Payongayong, \& Aidoo, 2003; Ravallion \& Lipton, 2005).

The significant difference between urban agriculture compared to commercial agriculture is evident in the labour relations in UA as explained in From Seed to Table (FStT). Working with the framework From Seed to Table, (Marielle Dubbeling, 2006) explained that the value chain of UA made it clearer for urban households to use members in accomplishing labour requirements. While mechanised agriculture can boost specialised inputs and systems, rural agriculture uses large plots accompanied by hired labours. Urban agriculture, whose main aim is feeding the households, extracts labour from among household members and this is one of the features that makes it attractive to urban households in PHC. Labour relations mobilises family, mediated by cash economy, gender and other employment alternatives - all in ways that are different from commercial and rural agriculture. 
(v) Proximity to Market: The rapid urbanisation in the global south implies an increasing pressure on urban areas for agricultural production because of demand for fresh harvests which UA offers to its host cities. As most fresh vegetables come from UA in close proximity to population concentrations (Mawois, Aubry, \& Le Bail, 2011). In 2011, researches said that Cuba's urban farmers provided the city's urban population with 8,500 tons of agricultural produce, 4 million dozen of flowers, 7.5 million eggs, and 3,650 tons of meat (Altieri \& Toledo, 2011; Viljoen \& Bohn, 2012). In Accra (Drechsel and Evans, 2010) said UA has improves the healthy eating habit of the urban population and fresh vegetables are sold to urban dwellers from the urban farms. In Kampala through the help of NGOs, UA has built the capacity of urban farmers and they are processing about 24 different foods from banana (Matoke) alone (Ngaido, 2004). Kampala UA workers said UA that started in the city as a livelihood strategy has now evolved into an industry that is lifting households above the poverty thresholds.

In rural agriculture, traders from the major markets and supermarkets troop into the farms during harvests and purchase their produce for reselling to other consumers. In commercial agriculture, they have an established market where their harvested produce is processed, packaged, preserved and delivered. The traders who buy in bulk have facilities to preserve these produces and this is one disadvantage that is associated urban agriculture workers. The UA workers work on the premise that they harvest their produce today and have the ones to eat then sell off the ones for marketing. If they have leftovers, they either dash to extended family members or risk losing them because of lack of storage and preservation facilities. Therefore, in urban agriculture the market is the immediate environment, including the city that houses the urban agriculture while commercial and rural agriculture market is broader.

(vi) Storage and Preservation: On a world-wide basis, post-harvest losses of durable crops are estimated at $10 \%$, but in the global south, losses of more than $20 \%$ are frequently encountered due to poor storage facilities among urban farmers (Kuusaana \& Eledi 2015; Roy 2005). In most cities in the global south including PHC, where UA is practiced, the post-harvest storage of some perishable crops and traditional methods of food preservation are used when they have leftovers from feeding and sales. Fishes are steamed, dried, coked; cassava is processed into garri and tomatoes 
are blended and steamed for preservation and storage.

When storage and preservation are considered at the entry point of UA, the majority of the farmers avoided going into UA of crops such as tomatoes that perish more easily. Such crops add little value to the business of UA workers without proper storage since it is a seasonal crop in PHC and once all the farmers harvest them to the markets there are surpluses and the market value plummets. After due consideration of this feature if an urban household wants to engage with UA, such households avoid UA of tomatoes on a larger scale but consider other crops (yam, maize, cassava in large scale). Overcoming the problems of waste (leftovers) in UA of $\mathrm{PHC}$ has been a problem especially in the peak of the harvest season where seasonal crops are harvested by all the urban farmers at the same time.

(vii) Relationship to the Environment mediated by built environment: Urban agriculture workers are transforming inner city spaces all over the world, rooftops, infrastructures, streetscapes and building skin into generative ecologies that support the lives of people, and pollinators. They are bringing into cities, and into plain view, the natural systems that sustain urban life (Pearson, Pearson, \& Pearson, 2010). Although these contributions of UA to the cities are glaring, some people still see urban land as mainly residential and not for farming (Brown-Luthango, 2011). Planning can move beyond this divide of the city and place of production by making urban land accessible to poor urban households desiring to practice UA (Marx, 2006). Development planners seem to forget that the city, and indeed each one of its inhabitants are part of nature as planning tends to neglect the UA-poverty linkages. The rebirth of urban agriculture offers hope for a more positive, regenerative relationship between natural systems and human communities as practice of UA depend on urban and peri-urban natural resources (Campbell, 1996; Lovell, 2010; Wilson, Velis, \& Cheeseman, 2006).

Conventional (rural and mechanised) agriculture make use of natural resources too but by their design, they are expected to produce more for market purposes and therefore uses more inputs (fertilizers and GMOs). These are parts of its design that makes UA distinct from them, operated on small plots of land in most cases, it is a stop gap between food production and poverty (Frayne, McCordic, \& Shilomboleni, 
2014). Though on its own, the nature of the built fabrics of some of our cities makes it very difficult to practice UA. Cities that have less space, more fragmented by other users, it is less able to use mechanised systems, less able to use pesticides and have more competitive users of such spaces makes UA practices difficult. Therefore, the built environment affects UA by getting in the way, affecting what kinds of activities can be engaged in, reducing plot size, providing access to infrastructure such as roads and water.

Summarily, this paper has explained in this section that to understand and appreciate the differences between urban, rural and commercial agriculture, due consideration should be giving to the seven features above. Understanding what households consider before engaging with or moving out of UA at the entry or exit points are significant. The understanding of land tenure, financing, labour relations, proximity to markets, storage and preservation and their relations with the environment being mediated by the built environment, will help to understand what UA is. Classification and definition of UA with the understanding of the contributions of these seven features, enables policies to understand what UA is and its contribution to the urban development.

\section{Classification of Urban agriculture}

Goldstein et al., (2016) gave an overview of the various approaches to urban production systems and the possibility to develop a typology to explore them. They identified the difficulty in arriving at a consensus typology that will form a sound basis for identifying basic development strategies for each type of UA and policy development and action planning as the main challenge to researchers. Classification of UA differs with the criteria used, location and size of farms (Drechsel \& Dongus, 2010; L. Mougeot, 2000), production aims, predominance of crops or animals or intensity of production (Barthel \& Isendahl, 2013; L. J. M. Mougeot, 2000; Tambwe, Rudolph, \& Greenstein, 2011). The broader research was more interested in the aim of UA than location or type of products or intensity of production. The aim of UA in $\mathrm{PHC}$ is to feed the households and understanding of the seven features stated above frames UA in that direction. This research focused on the aim of UA because most of the classification as will be shown below only capture part of the reality and suffers 
from clarity and differences between cities and region not forgetting overlap among systems.

Relating these overviews to the features of UA discussed earlier in this paper, it relates to the built environment, where UA practices is tailored to the particular city's-built environment. Therefore, classification of $U A$ is further divided into two types; the single criteria and the multiple criteria classifications (Scott et al., 2010). They named the determinants of single criteria as; location, main crop produced and animal raised, degree of market-orientation, scale and intensity of production. All of the above plus factors such as, access to irrigation water and location to next crop choice were used to classify the multiple criteria in Accra (Moustier \& Danso, 2006; René van. Veenhuizen \& Danso, 2007). These determinants are discussed in details below.

\section{Location}

This paper has made it clear that every definition of UA must do with the relationship it has with the particular city hosting it and the features of UA that made it attractive to such city. UA as we know from the three phases of debates that led to the definition discussed earlier, supplies fresh produce to the host city (Smit \& Nasr, 1992) and thus the location of UA is very important to fulfil this. In classifying UA, the location where the activities are carried out is used as an important criterion since this point to specific constraints and opportunities such as; degree of land access, land tenure situation, costs and time related to traveling, risk and closeness to market (Taiwo, 2014). There have always been efforts to distinguish between intra-urban agriculture (L. Mougeot, 2000) and this is done on the basis of distance to the city centre or travel time by public transport, administrative boundaries and population density. In relation to the intraand peri-urban debates, UA activities can take place in close to the city centre and far from city centre of the urban farmer (Agarwal, 2001; O. Cofie \& Awuah, 2008; Drechsel \& Dongus, 2010).

The UA practiced far from city centre have been said to have influenced the possibilities of combining agricultural with non-agricultural tasks e.g house chores, and other small businesses, leading ILO (2013) to define UA as an industry. The success in the practices of UA depends mostly on the tenure of the land that UA is practiced than just the location of such land (Barry \& Danso, 2014a; Otsuka et al., 2003; Steward, 2007). On her part, Dubbeling (2011) distinguished between UA on private' 
land (owned lease) 'public' land (parks, conservation areas, along roads/railways) and semi-public (schools, hospitals, prisons). She concluded that the sustainability of the location and specific cultivation system of UA is hinged on the land tenure system accessed by the urban agriculture workers. Therefore, relating this to the features of UA, the location of UA does not determine its success but the tenure of the land such UA is practiced.

\section{Main Crops Produced and Animals Raised}

The determinants of what to produce and how to produce them in UA are social, economic and physical factors. In most cities, the choice of what to produce in UA depends on the choice of the main diet and food of people living in such city (Oladapo Sam, 2014; Ward \& Shackleton, 2016). In Nigeria for instance, during and after the SAPs, households that were forced to abandon their assets (land) in the cities and relocate to the rural areas to continue agriculture, did not abandon their traditional crops (Nwagbara, 2011). During this same period, because the local diets (e.g. garri, eba, fufu) were not part of the food imports, urban farmers who moved towards the edges/periphery of the cities maintained planting them (Arowosegbe, 2016). The climate, culture, soil condition, socio-economic conditions and most especially the informal networks these people operated in, influence these dynamics (Eigenbrod \& Gruda, 2015). They borrow, share and replant seeds between the networks and make use of shared labour, which developed out of these informal networks and relations that these urban farmers built with time (Taiwo, 2014). The same applies to livestock, the goats kept in PHC (southern Nigeria) are different from that raised in the Northern part of Nigeria (Aduku, Aganga, Yaakugh, \& Philip, 1991).

Crops production and livestock keeping tends to be maintained by different households in urban production system but both are greatly influenced by land tenure. According to (Adeoti et al., 2011) households that have a secure tenure practiced mix farming (crops, animals and poultry). There is still significant linkage between these urban farmers and the rural farmer in the area of sharing (seeds, compost, farm tools, indigenous knowledge). Three main production systems were identified by Vagneron (2007) in UA and they are; specialised production system which is devoted to a single crop or animal. Mixed production system, which combines two activities and hybrid production systems, which combines more than two activities. 


\section{Degree of Market-Orientation}

Urban agriculture consist of two distinct and separated subsectors and they are, commercial horticulture and the crops/livestock industry (Eapen, 2001; Meagher, 1995; Mkwambisi, Fraser, \& Dougill, 2011; L. J. M. Mougeot, 2000). Both of these subsectors of UA have a significant effect on food security in the particular cities where UA is practiced (O. O. Cofie, Veenhuizen, \& Drechsel, 2003a; Kenneth Lynch, Maconachie, Binns, Tengbe, \& Bangura, 2013). In most cities in the urban global south, an important part of UA production is for the household consumption and the surplus is then sold. This goes on to support the argument that poor urban households turn to UA because of poverty and UA have lifted households out of poverty too (Bezemer \& Headey, 2008; O. O. Cofie et al., 2003a; McNicoll, 2011). However the importance of market-orientation in UA, both in volume and economic value should not be disregarded because of its value to the city and those engaging with it (Brinkley, 2012).

Despite these contributions of urban agriculture to the urban economy and urban lives, land policies in most cities are yet to accept it as part of the urban productive system. In cities of South Africa, there are reports that urban dwellers see the city as place for housing and not for farming (Brown-Luthango, 2011). More generally, the mediated intimate relationship between food production and cities became increasingly and thoroughly disconnected over the course of the 20th century (Steel, 2008). The cities became less productive for agriculture and food were supplied from the rural areas to feed the cities.

\section{Definitions and Development of Urban agriculture}

This paper's definition of urban agriculture is therefore that:

UA is an occupation located within (intra-urban) or on the edges (peri-urban) of an urban centre, that considers its social network in relation to the urban area it is located. The practice of UA grows or raises, processes and markets/distributes a diversity of food and nonfood products, reusing mainly human and material resources, products and services found within and around that urban area. It in return supplies human and material resources, products and services and distributes a diversity of agricultural products to the same urban area mostly within the same day of harvest. 
This paper understands that definitions of urban agriculture appear bound up with urban poverty reduction strategies because of its relationship with the urban poor and strategies that will reduce poverty. In arriving at the definition of urban agriculture above, this paper explores the debates around three phases of development in Nigeria and acknowledged the positives of their views and incorporated them into the definition above. The term, 'grow' in the definition means the production phase in the UA chain, processing is during commodification to add value to the produce. Food and non-food products of UA include (fruits, vegetables, poultry, animals, medicinal herbs and wastes generated and reused). 'Supplying them the same day of harvest' means the marketing/distribution phase of UA chain, supplying the produce fresh from sources to its end users. Therefore, the value chain phases of UA (production-processingmarketing/distribution-consumption-recycling) are linked with the various aspects of informal economy in PHC.

\section{Defining the Production Phase of Urban agriculture}

This paper's definition of the production phase of urban agriculture is therefore that:

The production phase of urban agriculture refers to the phase of planting crops, herbs and flowers, rearing animals, fish and the people that are physically engaged in the day-to-day running of their farms. They own the activities that happens on the farms but 'might' not necessarily be the principal owner of such land. They participate in this activity for various reasons, feeding and marketing being prime examples.

\section{Contemporary African Urban Farmers in Perspective of Livelihood Diversity.}

Urban agriculture as an intervention has it main objectives; providing fresh food for the urban dwellers, informal employment opportunities and reducing poverty (O. O. Cofie, Veenhuizen, \& Drechsel, 2003b; L. J. A. Mougeot, 2006; René van Veenhuizen, 2006). But this has come with a cost and that has to do with the strenuous labour and vulnerabilities (health, loss of assets, environmental disaster) associated with production in UA (Barrett, Reardon, \& Webb, 2001; Ellis, 2006). In many African cities, vulnerabilities have resulted in people engaging in UA production to always 
diversify ${ }^{5}$ (Oumer \& de Neergaard, 2011). Thus, to achieve the desire of this research, understanding the role UA play in the livelihood of poor urban households in PHC will be key. The diversification of urban households into, within and out of UA are for different reasons, and are given thus; Contrast between survival and choice (Dan Maxwell, 1997), survival and accumulation (Hart, 2008), corresponds to the migration literature to the push versus pull reasons why people migrate (Bigsten \& Moene, 1996).

The urban farmers in African cities such as Kigali, Accra, Harare, Dar es Salaam, Sun City, Ibadan and Kampala are highly gendered 6 (Awumbila \& Ardayfio-Schandorf, 2008; Battersby et al., 2014; Guyer \& Lambin, 1993; Daniel Maxwell, 1999; Mlozi, 1995). These are African cities have development challenges like PHC but the city authorities are using UA built into development plans in addressing those urban challenges ${ }^{7}$ (Halkias, Nwajiuba, Harkiolakis, \& Caracatsanis, 2011). Urban households tap into the social network created by themselves or inherited to expand their social network of UA (Bigsten, 1996; Chen, 2007; Meagher, 2005). These informal networks are built from the homes, markets, farms, churches, mosques, work places and leisure places (Meagher, 2006).

Although most of the UA workers are from the low-income urban households, there are still rich and middle-class households practicing UA. There are some other households who are not rural or from poor background but took to UA either to make more money or leisure (Yves Cabannes \& Raposo, 2013; Whittinghill \& Rowe, 2012). Women represent an important portion of the urban agriculture population because they appear to take more direct responsibility to feed the households (McNicoll 2011; Fonchingong 1999; Daley \& Englert 2016). In the global south, urban farmers are mostly new immigrants into the city, wives of school teachers and church workers, informal security guards that have access to land not developed yet and indigenes that inherited farms from their families (Ezedinma \& Chukuezi, 1999).

\footnotetext{
${ }^{5}$ They diversify into other informal economic activities and education for their children while still engaging with urban agriculture. They do thisto make the children have a better prospect other than UA alone (Ellis, 2000).

${ }^{6}$ The men and women engaging with UA have the roles they play as members of a household on and off the farms.

${ }^{7}$ Some of the urban challenges are hunger, shelter, food security and poverty.
} 


\section{Urban agriculture as a Permanent Part of the Urban System.}

From the work of Tevera \& Simelane (2014) UA is subdivided 8 into two types (intraurban agriculture). My research focuses on the broad use of UA to accommodate agricultural production within and on the edges of the city ${ }^{9}$. Studies use the term intraurban agriculture for agriculture that takes place in the inner city and peri-urban for that on the edges of the city (L. J. M. Mougeot, 2000; Tevera \& Simelane, 2014). Most cities in the developed countries have vacant and under-utilised spaces that are or can be used for UA and that is why this concept (inter and peri-urban) came up. In most Nigerian cities, after the introduction of SAP, agricultural production moved towards the edges ${ }^{10}$ (peri-urban) of the cities (Afrane et al., 2004; Shimada, 1999). In the inner cities, urban farmers still make use of schools, churches, unused land and $\mathrm{road} / \mathrm{rail}$ sides but they have all come with various challenges. These challenges range from theft, vandalism, public health risks and lack of irrigation means or irrigating vegetables with untreated wastewater. The wastewater has caused health challenges to consumers of such produce but RUAF and IWMI taught UA workers in Accra how to irrigate vegetable with such water and reduce contaminations.

\footnotetext{
${ }^{8}$ They divided UA into two intra and peri-urban to explain what the concept is and how its interactions with the built environment is received by other users of such environment.

${ }^{9}$ By using the broad term UA, my research is holistically encompassing both types into one as they intertwine in PHC and cannot be separated. By using the term urban agriculture, I am referring to UA practiced in the inner city and on the edges of the city as seen in my fieldwork (location of farms).

${ }^{10}$ Urban farmers were encouraged to let go of their urban land and move rural and peri-urban to continue producing more and urban land were also in demand for housing and other urban use.
} 
Potential of Urban Agriculture as a Poverty Reduction Intervention Policy.

In the previous section, I explained how urban agriculture have become permanent part of the urban productive system. Since it is urban based and people turn to it because of poverty, I will move further to explain how it reduces urban poverty in the global south. Urban agriculture contributes greatly to the reduction of urban poverty, hunger and ensures environment sustainability (Lee-Smith, 2010; René van. Veenhuizen \& Danso, 2007). It does these through; the urban food system and nutrition, development of local economy, social impact and contributes to urban economic development. These potentials of urban agriculture are discussed below.

\section{Urban Food Security and Nutrition}

The contribution to urban healthy eating and food security of poor urban households is the greatest contributions of UA in the global south. Factors such as lack of purchasing power, inadequate, irregular and unreliable access to food has been seen 
as reasons why poor households turns to urban agriculture in the global south (Taiwo, 2013; Tambwe et al., 2011). It is evident that poverty motivates poor urban households towards engaging with urban agriculture (Mkwambisi et al., 2011). As Steel (2008) put it, food and the city have built a cordial relationship but the cost of supplying food to the cities from the rural areas and the intricacies of its distribution has been a challenge to cities till today. As a consequence, if UA is not harnessed by city authorities, the difficulties faced by poor urban households will only increase and add to the urban food insecurity (Battersby et al., 2014; Shillington, 2013).

As seen in cities such as Accra, Kampala and lbadan where UA is practiced, when these urban farmers have had their food security secured, they tend to sell to add extra money to the households' savings (Yves Cabannes \& Raposo, 2013; Chilowa, 1998). Studies in Kampala shows that UA which started as a survival strategy has now become a business where households are making profit on their investments (Battersby et al., 2014; Mawois et al., 2011; Tambwe et al., 2011; Warshawsky, 2016). These urban farmers are feeding urban residents by supplying large quantities of food into the urban markets. Accordingly, FAO (2013) estimates that 200 million urban residents produce food supplying about $30 \%$ of the world food to the urban centres that host them. These are ways $U A$ is contributing to urban food security and nutrition in the world.

\section{Local Economic Development}

UA is an important source of income for significant number of urban households (see chapter 5). In addition to the money these households make from selling their produces after feeding, they also save money by growing their households' food needs. This is significant since it is estimated that poor households spend between $60 \%-70 \%$ of their household income on food purchases (Maxwell 1999; Dubbeling 2011). Since urban agriculture is based in a particular city and considers the economy of such city (features of urban agriculture section 2.2), it helps develop the local economy by supplying the city's food needs. Gains including funds raised from crops, animals and other outputs sales are reinvested into other sectors of the city economy such as school fees, taxes, transportation, glossaries, clothing and rent payments. 
Urban agriculture improves the growth of small scale industries as seen in the definition of the (ILO, 2013; WIEGO, 2010) where they defined UA using the term "industry". UA activities are supported through the provision of necessary agricultural inputs and processing/supplies of the by-products through NGOs and government agencies. Therefore, households that are not involved in the production phase of UA can take advantage of the processing phase or marketing/distribution phase or recycling and thereby making this industry (UA) a viable intervention for urban households. These are ways urban agriculture contributes towards the local economy development of its host cities.

\section{Social Impact}

UA plays a critical role in the lives of disadvantaged poor urban households, which may include (HIV/AIDS-affected households, disabled people, widows/female headed households, unemployed youths and migrants). It does these through its mediation as a poverty reduction intervention strategy (Ellis \& Mdoe, 2003) and social inclusion (Yves Cabannes \& Raposo, 2013; O. O. Cofie et al., 2003b; Niehof, 2004). With the broader aim of integrating them more firmly into the urban network and providing them with a decent livelihood and preventing social problems such as drugs and crimes (Gertler, 2010; René van. Veenhuizen \& Danso, 2007). RUAF did this in its project called women feeding cities in South Africa and lives of women affected by HIV/AIDS improved (McNicoll, 2011). UA farms acts as healing and educational sites for citizens in providing therapeutic spaces to rehabilitate members of the community through interaction with nature (Adedeji \& Ademiluyi, 2009; O. O. Cofie et al., 2003b; L. J. M. Mougeot, 2000).

\section{Contribution to Urban Development Management}

Thinking of the rural-urban linkages in the global south, where foods are produced in the rural areas to feed the cities and the cities' domestic wastes are transported and dumped in the rural areas (Orsini, Kahane, Nono-Womdim, \& Gianquinto, 2013). UA contributes to manage this situation through composting, making use of poultry and domestic wastes thereby turning urban waste into productive resources (Gupta \& Gangopadhyay, 2006). Wastewater reuse in the irrigation process and maintenance of biodiversity through the replanting of seeds and tubers are part of the sustainability aspect of UA. It also reduces the ecological footprint of the cities by producing fresh 
food close to the consumers, something Smit and Nasr, (1992) called food with the farmer's face. Therefore, UA contributes to urban development management by reducing energy used for transportation, packaging and cooling/preserving food that feed cities.

\section{The Phases of Land Reforms in Nigeria and the place of Urban Farmers}

The nationalisation of land administration currently practiced in many African states including Nigeria have been informed by the 1987 World Commission on Economic and Development (WCED). They said if natural resources are managed and administered by the government that it will be evenly distributed ${ }^{11}$ and less cumbersome or problematic (Aribigbola, 2008). Today (2019), such is not the case in Nigeria where citizens are experiencing the worst scenario in the petroleum industry that is managed by the federal government, and proceeds shared within the three tiers of government (Bruno Imokhai, 2015). This position that is constitutionally adopted and the management of natural resources in Nigeria, is adding more concerns than joy to the citizens.

Socio-cultural and political institutions regulate natural resources in urban areas but these institutional arrangements do not ensure equal access. On the contrary, Bryld (2003) observes that the central control of natural resources in developing countries has greatly degraded the land and falls short of the ecologically sound practices. It is said that the traditional systems wherein local people used to manage natural resources during the pre-colonial era led to more equal distribution and access (Bowyer-Bower \& Shiva 1996; Allendorf 2007; Simiyu 2013; Agrawal, Arun and Ostrom 2001; Agarwal 2001). When natural resources are not evenly distributed to all residents, it rather generates socio-economic, gender and ethnic inequalities. These are all evident in Nigeria currently ${ }^{12}$ and finding a way to manage and equally distribute natural resources found in urban areas for its citizens will be welcomed.

This implies that in Nigerian cities, whatever way one looks at, it has created a huge gap between the rich and the poor, indigenes and non-indigenes, families and households. These groups are those that form the nucleus of an urban area in Port

\footnotetext{
${ }^{11}$ Proceeds from the sales of crude which the Nigerian economy largely depends on.

${ }^{12}$ The demand for resource control by the Niger delta region, the militancy and unrest in the region that has resulted in violent kidnapping and destruction of oil installations are some of the evidence.
} 
Harcourt and other cities of Nigeria. Furthermore, natural resources (such as; crude oil and gas) are said to belong to the federal government of Nigeria, wherever it is found within its borders. The part of the Land Use Act 1978 which gives exclusive ownership of natural resources to the federal government" and the Liquefied Natural Gas Act (LNG) 1990 and 1993 makes it impossible for personal ownership of such natural resources in Nigeria. This has only created more security challenges in the Niger Delta region as the agitators are saying they are not having a fair share of the dividends of what their environment produces. Therefore, leaving the control of land market in the hands of the government as currently practiced in most of the cities of Nigeria makes it impossible for the urban poor to access land.

Poor urban households use strategies in overcoming myriad challenges militating against access to urban land in Nigerian cities. Acting collectively, forming cooperatives, acting on their fundamental human rights and social networks are some of the strategies adopted (Chuba \& Eziyi, 2011; Ellis, 1998; Meagher, 2005; Ostrom, 2000). Also, Aluko (2011) opines that a mixture of customary, informal and formal practices are employed in securing land from indigenous landowners, principally aimed at ensuring customary and statutory legitimacy as well as secured tenure. Here an individual buys land informally and try to formalise the land title through the registry to have a secure tenure and this helps save the land from dubious land speculators. There are practices where cooperatives and associations secure land for their members by acting as sureties.

Availability and access to land is generally recognised as a prerequisite for sustainable urban livelihood for the low-income earners in urban areas of the global south. However, it has been observed that access to land for urban poor in urban areas in many of these countries is becoming highly problematic (Brown-Luthango, 2011). In African countries such as Nigeria, urban land has increasingly become a commodity to be acquired and sold to the highest bidder ( Chuba \& Eziyi 2011; White 1986). The low-income earners who lack economic and political power and have come to the city looking for what to do, what to eat and where to live (work, food and housing) cannot gain access to urban land. Thus, urban land allocated for school-to-land programmes 
in the late 1980s were taken away by the government of Sir Dr Peter Odili ${ }^{13}$ in 2005 and converted for real estate purposes in PHC. Therefore, urban households are experiencing severe land accessibility challenges and that hinders their ability to engage with urban agriculture (Umukoro, 2012).

There are three phases of Land reforms in Nigeria from the 1914 when it became a British colony and protectorate till the 1978 when Land Use Act became functional. Understanding these phases of land rights in relation to the citizens of Nigeria and its government will make the recommendations on how land should be appropriated meaningful. It is to these phases of land reforms in Nigeria I turn to in the next section to explain how land access and tenure has fared in Nigeria during these periods under review.

\section{The British Rule Phase}

The first reform started at the beginning of the 20th century when Britain made a colony and protectorate of Nigeria, whereby there were multiplicity of land tenure systems in the country (Fabiyi, 1984). Apart from the system in the Lagos colony, which was then the federal capital and was given a special treatment, where an English freehold ${ }^{14}$ system had been established following its annexation in 1861, these phase can be sub-divided broadly into two (Braimoh \& Onishi, 2007). The first obtained in northern Nigeria where the colonial administration had placed all lands under the control and subject to the disposition of the Governor. This was on the basis that the Maliki Law operated by the Fulani over much of Hausa-land in the 19th century confers on the colonial conquerors the rights to the land of the conquered. This system, if it was still in operation today in Nigeria would be advantageous ${ }^{15}$ to powerful landless communities and their weaker neighbours that have more land.

An Ordinance of Government of Nigeria in 1953, directed that the Governor should hold and administer land for the use and common benefit of the native peoples. Any

\footnotetext{
${ }^{13}$ Sir Dr Peter Odili was the executive governor of Rivers State from 1999-2007 and exercised his powers as enshrined in the Land Use Act to revoke the School-2-Land's land and converted it to real estate development.

${ }^{14} \mathrm{~A}$ freehold is the common ownership of real property, or land, and all immovable structures attached to such land, as opposed to leasehold, in which the property reverts to the owner of the land after the lease period has expired. ${ }^{15} \mathrm{Communities} \mathrm{that} \mathrm{have} \mathrm{influential} \mathrm{and} \mathrm{wealthy} \mathrm{persons} \mathrm{tends} \mathrm{to} \mathrm{outsmart} \mathrm{those} \mathrm{that} \mathrm{do} \mathrm{not} \mathrm{have} \mathrm{such}$ in terms of project allocation, elective positions and general representation in the country.
} 
native or native community lawfully using and occupying land in accordance with native law and custom enjoys a right of occupancy protected by the Ordinance and no rent is paid in respect of such rights. In the case of all other persons, no title is valid which the Governor has not conferred. In this case, the governor is empowered to grant rights of occupancy for definite or indefinite terms, to impose conditions and to charge rents. The Ordinance lays down maxima of 1,200 acres for agricultural grants and 12,500 acres for grazing purposes (Aribigbola, 2008; Awotide et al., 2010). Considering this ordinance and the present situation where herdsmen and farmers are clashing in every part of Nigeria, if kept it would stop open grazing and such confrontation.

According to (Lynch, Binns and Olofin, 2001 and Guyer et al., 2007) the arrival of Colonial rule from 1900, brought about the changes in land administration in Northern Nigeria. They said the first thing done under the British rule was to take over all rights of land from the Sokoto ${ }^{16}$ Caliphate ${ }^{17}$ and vest it in the hand of the British government. Accordingly, land in the region was classified as crown land, which was vested in the care of the governor in trust of Her Majesty (Decker, 2008). The other called public land was vested in the care of the Governor for the people. However, whether in Northern or Southern Nigeria, land was considered by the people as right rather than privilege. Thus, access was not only through kinship but also allegiance to a local sovereign ${ }^{18}$ and it determines a relation to land. Considering these interactions with land in Nigerian cities, the position of the citizens at the beginning of the 20th century was that land was not sold.

The citizens believe that to sell land to a stranger or immigrant is to render the security of the community concerned a hostage (Fabiyi, 1984). Policies like this will be very much appreciated by the urban poor households engaging with UA who depends on land for agricultural production according to (Mabogunye, 2010). Hence, when the colonialists came, everywhere they went, they were told that there was no tradition of

\footnotetext{
${ }^{16} \mathrm{~A}$ state in Nigeria and the ancestral capital of Northern Nigeria

${ }^{17}$ The Sokoto Caliphate was an independent Islamic caliphate in West Africa. Founded during the Jihad of the Fulani war in 1809 by Usman dan Fodio. The Caliphate was abolished when the British defeated the caliphate in 1903 and put the area under the Northern Nigeria Protectorate (Fabiyi, 1984).Developed in the context of multiple, independent Hausa Kingdom at its height the Caliphate linked over 30 different emirates and over 10 million people in the most powerful state in its region and one of the most significant empires in Africa in the nineteenth century (Ayanniyi et al., 2014).

${ }_{18}$ This is the traditional beliefs of the people and it is evident in the libation and incantations they do during the exchange of land rights to a new buyer.
} 
alienating land. Indeed, such was the situation that the British Colonial Office had to set up a special Lands Committee to investigate the land tenure systems in all of its West African colonies in 1912 to confirm the general customary laws and practices with respect to land (Ayanniyi, Balarabe, \& Mahmoud, 2014).

Yet, the extensive labour migrations that colonialism set in motion could not go on without land being alienated to strangers and migrants. Whether in the urban or rural areas, transactions in land gradually emerged in all parts of the country (lkejiofor, 2006). Unlike in pre-capitalist society, such transactions also entailed the individualisation of land. Such land remained in individual ownership until the demise of the owner when, through the inheritance law, it again became subject to multiple ownership claims. The introduction of perennial crops such as cocoa, rubber, planted oil palms, all of which meant fixed cultivation, replaced the transient traditional shifting cultivation under group control by an enduring right of individuals. By the same token, building a house in an urban area entailed establishing an enduring right on the particular plot of land. Thus, as the colonial era progressed, land alienation and sales not only grew in volume and geographical spread but also became the cause of considerable litigation and communal strife, often resulting in violent confrontation.

The second type of land transaction and contrast to that which was practice in the North was in southern part of Nigeria, and recognised that land was owned by lineages or extended families. Individuals have only right of use on such family land and cannot inherit or own it, therefore selling or lending it to a third party was prohibited (Ebeku, 2002). The only land held at the Governor's disposal was that which had been expressly acquired for public purposes as Crown land. The only control imposed by law on the lineages and other local land-holders was an obligation to seek the consent of government when rights are being conveyed to strangers or immigrants. This they say make them more secure as any stranger coming to live with them usually pass through the king and a form of documentation is done.

This land tenure system of southern Nigeria created several problems for land management in the country. First, it encouraged the practice of multiple sales of the same land to different buyers by land-owning families in the absence of a titling, and appropriate registration mechanisms for transactions in land (Mabogunye, 2010). This 
is made possible as different members of the family can claim to different buyers to be the authentic owner of such land. Also, particularly after the nation's political independence (after 1960), it led to rise in the prices of land for urban and infrastructural development due to assumption that cities will provide better life opportunities (Oladapo Sam, 2014). There was not any definite place to verify the authentic owners of land and as such land speculators continually took advantage of the loopholes and defrauded potential buyers. In cities of Nigeria, including PHC, poor farming households were encouraged to part with their urban land for relatively small amounts compared to what the speculators (third party) made from laying the land out for sale (Taiwo, 2014). This promoted increasing inequality in land ownership and increasing landlessness among the poorer segments of the population.

\section{Promulgation of the Land Tenure Law of Northern Nigeria}

After Nigeria's independence in 1960, the Land Tenure Law of Northern Nigeria 1962 was promulgated (McDowell, 1970). Analysts pointed out that the legislature submissively adopted substantial part of the Ordnances, affecting only a brief cosmetic face-left (Fabiyi, 1984; Umukoro, 2012). With this, the problems ${ }^{19}$ of land tenure and administration persisted. There came problems of land speculations, racketeering, faulty and skewed distribution, monopoly and exorbitant demands for compensations whenever the government demanded land for development. Land tenure became the most complex and most delicate of problems facing agriculture (at all levels and at all locations) in Nigeria (Fabiyi, 1984; Guyer et al., 2007). Land that was said to belong to the people and should not be sold then become a commodity that the highest bidders were having a field day, deciding what to buy and at what point, thereby leaving the poor urban households struggling. This affected the way urban land was administered to the public and the effect it has on production for the urban households practicing urban agriculture became more severe.

\footnotetext{
${ }^{19}$ Basic principles of land tenure law of Northern Nigeria 1962 include; The basic principles of land tenure in Northern Nigeria are contained in sections 4, 5 and 6 of the Land Tenure Law and are as follows: (a) "... the whole of the lands of Northern Nigeria, whether occupied or unoccupied, are hereby declared to be native lands." (b) "All native lands and all rights over the same are hereby declared to be under the control and subject to the disposition of the Minister and shall be held and administered for the use and common benefit of the natives, and no title to the occupation a use of any such lands by a non-native shall be valid without the consent of the Minister." (c) "It shall be lawful for the Minister to grant rights of occupancy to natives and non-natives." (McDowell, 1970). These principles are drafted into the Land Use ACT 1978 and as such the issues of land not evenly distributed persists.
} 


\section{The Land Use Act 1978}

The period between 1975 and 1978, was the time when an attempt at having a sense of national purpose and wellbeing was made with the promulgation of the Nigerian Land Use Decree No 6 (Land Use Act, 1978). By the provision of the Act, all lands within the territory of each state are vested in the Governor of that state and such land is held in trust and administered for the use and common benefits ${ }^{20}$ of all Nigerians. The Act heralded policies such as the power of the Governor to declare territory within the state urban or rural and decide what happens in their state's land (Land Use Act, 1978; Ako, 2009). Another of such policy is that which holds that urban land is meant for housing and other urban industrial use. This means that although people still practice urban agriculture in and on the fringes of $\mathrm{PHC}$ and other Nigerian cities, but it is officially illegal according to this law.

By the Land Use Act 1978 all lands comprised in the territory of each state with the exception of land belonging to the Federal government or its agencies at the commencement of the Decree are vested in the Governor of the State. The meaning and effect of vesting all lands in the government is that private ownership is hereby abolished and the title of the former private owners transferred to Government (Land Use Act, 1978).

According to NBS (2010), half of Nigeria population lives in cities; $80 \%$ live in slum conditions including waterfronts. Rapid growth of cities has engulfed nearby towns and villages, pushed back forests and coastal mangrove areas, and created conditions of congestion, poor health, and poverty (USAID, 2013). Sixty-four percent of Nigeria population lives on less than $\$ 1.25$ per day; women-headed households are among the poorest (Halkias et al., 2011). Prior to 1978, Nigeria system of customary land tenure provided families and individuals with use rights to rural land for agriculture and urban/town plots for housing that were heritable within families and lineages. In 1978, the Land Use Act (or Decree) was enacted. The objectives of the Land Use Act were to: (1) make land accessible to all Nigerians; (2) prevent speculative purchases of communal land; (3) streamline and simplify the management and ownership of land; (4) make land available to governments at all levels for development; and (5) provide a system of government administration of rights that would improve tenure security (Land Use Act, 1978; USAID, 2013). The Land Use Act of 1978 is incorporated into

\footnotetext{
${ }^{20}$ This includes disadvantaged urban households and groups that might need land for the purpose of engaging with urban agriculture.
} 
the 1999 Constitution, making it difficult to revise or replace (Government, 2007). An effort to introduce new land reform legislation was buried in committee in March 2010 and it is not likely to resurface until the inauguration of the $9^{\text {th }}$ National Assemble (June, 2019).

Section 315 (5) (d) of the 1999 Constitution (as amended) specifically listed the Land Use Act as one of the existing laws that has been given effect by section 315 (1). Although the federal government puts forward the argument that the Land Use Act was enacted to curb the problems of multiple and complicated land tenure system in the country and to make land accessible and affordable for investments and developments, the Act has modified almost all the rights of land owners in Nigeria (Land Use Act, 1978).

A constraint of the Act on UA is the insecurity of tenure regarding urban "undeveloped land" which may be in use for agricultural purposes. By the provision of the Act all lands in 'urban areas' are primarily for residential and other urban land demands. Thus, no formal provisions was made for agricultural purpose in urban area but 36(2) quoted below tried to give right of use but complicated by $3,34(5,6)$ of the Act (Land Use Act, 1978; Joachim, Kamarudin and Aliagha, 2015). Ideally urban farmers would like to obtain access through a formal system, (ownership, rent/lease) permit but in the case of urban centres in Nigeria currently, it is difficult for the farmers to have this desired access, owing primarily to the position of the law (Bryld, 2003). This constitutional situation in the way land is administered in Nigeria is different from what is practiced in Kampala and Accra to address similar situations (Barry \& Danso, 2014b; Nkurunziza, 2008). These systems of land use planning (practiced in Kampala and Accra) helped in legalising UA and improved the livelihoods of the urban households practicing urban agriculture in those cities.

36 (2) Any occupier or holder of such land, whether under customary rights or otherwise howsoever, shall if that land was on the commencement of this Act being used for agricultural purposes, continue to be entitled to possession of the land for use for agricultural purposes as if a customary right of occupancy had been granted to the occupier or holder thereof by the appropriate local government and the reference in this subsection to land being used for agricultural purposes includes land which is, in accordance with the customary law of the locality concerned, allowed to lie fallow for purposes of recuperation of the soil. 
There is an increase of rural-urban migration in the city of Port Harcourt Nigeria, owing to the status of the city as the petro-economy headquarters in the country. The same way urbanisation and its adjoining urban poverty is on the increase in the global south coupled with hunger (Yves Cabannes \& Raposo, 2013; Crush, Frayne, \& Pendleton, 2012; Sathuraman, 1976). The condition of poverty in cities has been associated with lack of access to urban natural resources (Rakodi 2003; 2011Ellis 2006; Swaminathan 1996; Igbedioh 1993) and poor management of urbanisation (Fox \& Goodfellow 2016; Drechsel et al. 2010). Poor planning and misplaced intervention programmes have led to poverty greeting you when entering cities of the global south such as Port Harcourt. The most significant sign of poverty is seeing beggars in the traffic and under the bridges begging for alms to feed, this has led to the question, 'where is the place of food production in our cities'?

34(5) Where on the commencement of this Act the land is undeveloped, then (a) one plot or portion of the land not exceeding half of one hectare in area shall, subject to subsection (6) of this section, continue to be held by the person in whom the land was so vested as if the holder of the land was the holder of a statutory right of occupancy granted by the Governor in respect of the plot or portion as aforesaid under this Act; and (b) all the rights formerly vested in the holder in respect of the excess of the land shall on the commencement of this Act be extinguished and the excess of the land shall be taken over by the Governor and administered as provided in this Act.

By their nature, the dominance of the built environment makes it difficult to produce sufficient food for the urban population. But food supply and cities have built close relationship since the very first emergence of cities (Steel, 2008). Focus has been on the relationship of "the cities' and rural areas where food was supplied from to feed the cities (Fonchingong 1999; McNicoll 2011; L. J. M. Mougeot 2000; Crush et al. 2012). The cost of producing and transporting these foods to cities couple with the governance of these supplies became a major concern to planners. Part of the reason for these concerns is the obvious reliance of cities on the production of food in the rural hinterlands. This remains an issue for almost all cities today. However, what such analyses tend to overlook is that practices of urban agriculture have probably coexisted within cities for centuries.

To address this situation in cities such as PHC, I think section 3, 35 (5) (6) and 36 (2) 
of the Land Use Act 1978 should be revisited or Governors of states in Nigeria should act and save the day for UA.

Section 3: Designation of urban areas: Subject to such general conditions as may be specified in that behalf by the National Council of States, the Governor may for the purposes of this Act by order published in the State Gazette designate the parts of the area of the territory of the State constituting land in an urban area.

With the power vested in the hands of Governors over land in their various states and most especially urban land, it is the governor's power to decide what happens and where. Section 36(2) gives right of use to those that own urban land and using it for agricultural purposes before the Act was promulgated. Section 34(5) (6) reduced such land allowing the landowner to retain just one plot while the government took ownership of the rest without compensation. Section 3 gives the Governors the power to declare any part of the state urban and laws affecting urban is applicable to such area. Therefore, if an indigene owns more land and the government wants it, declaring where the land is located as urban makes section 34(5) (6) applicable (see appendix 7 for Land Use Act 1978).

\section{Conclusion}

This paper begins with exploring the implications of the concepts that appear in the thesis. This research defines the terminologies to the context of this thesis in order to enable readers to be abreast with the research. The characteristics of urban agriculture, its role and relationship to urban poverty are analysed. It differentiates urban agriculture from mechanised/commercial agriculture and rural agriculture. The distinct elements that differentiate UA from other conventional agricultural practices are addressed in the chapter. The UA is viewed as a product that meets the needs of the people. To achieve this objective, the main features of UA are analysed, including the benefits to the global south urban dwellers who engage in the practice. The research explored the definitions of urban agriculture through different development phases. A working definition of urban agriculture and also the definition of the production phase of urban agriculture is made clearer in this chapter of the research.

Given the importance of historical roots of urban households engaging with UA, the research explored the contemporary African urban farmer from a historical perspective 
linking it to livelihood diversity. The experiences from other African cities where UA is practiced and the purposes it has served such cities are analysed from historical perspective. With these contributions in mind, the research concludes that urban agriculture would remain a permanent part of the urban productive system. The chapter explains why UA is subdivided into two parts (intra- and peri-urban) and why my research studied them as indivisible. This paper further explores the potentials of urban agriculture as a poverty reduction intervention. It highlighted the role UA is playing in reducing hunger and malnutrition among the urban poor, reduction of poverty and ensuring urban sustainability.

In this paper, hindrances to the development of urban agriculture in Nigeria is explored by reviewing the Land Use Act of 1978 and the place of urban agriculture in the cities' development plans. Three phases of land reform in Nigeria are discussed and its implication on urban households' livelihoods. The various sections of the Land Use Act 1978 that hindered the practices of UA in Nigeria cities are referenced in the chapter. To support the argument that UA should be defined in relation to the particular city hosting it and its economy, the research classified urban agriculture and critiqued researchers that define UA broadly without using the findings of their UA research to determine what it means to those engaging with it. It further reviews an overview of the various approaches to urban productive system and suggested typology to explore them. 


\section{Bibliography}

Adedeji, O. H., \& Ademiluyi, I. A. (2009). Urban agriculture and urban land use planning: Need for a synthesis in metropolitan Lagos, Nigeria. Journal of Geography and Regional Planning, 2, 043-050.

Adeoti, a I., Oladele, O. I., \& Cofie, O. (2011). Sustainability of livelihoods through Urban Agriculture: Gender dimensions in Accra, Ghana. Life Science Journal, 8(2), 840-848.

Aduku, A. O., Aganga, A. A., Yaakugh, I. D. I., \& Philip, D. O. A. (1991). The marketing of goats in northern Nigeria. Small Ruminant Research.

Afrane, Y. A., Klinkenberg, E., Drechsel, P., Owusu-Daaku, K., Garms, R., \& Kruppa, T. (2004). Does irrigated urban agriculture influence the transmission of malaria in the city of Kumasi, Ghana? Acta Tropica, 89(2), 125-134.

Agarwal, B. (2001). Land Rights and Gender. In International Encyclopedia of the Social \& Behavioral Sciences (pp. 8251-8256).

Aidoo, K. E. (1993). Post-harvest storage and preservation of tropical crops. International Biodeterioration \& Biodegradation.

Ako, R. T. (2009). Nigeria's Land Use Act: An Anti-Thesis to Environmental Justice. Journal of African Law.

Altieri, M. a., \& Toledo, V. M. (2011). The agroecological revolution in Latin America: rescuing nature, ensuring food sovereignty and empowering peasants. The Journal of Peasant Studies, 38(3), 587-612.

Aluko, O. (2011). The Effects of Land Use Act on Sustainable Housing Provision in Nigeria: The Lagos State Experience. Journal of Sustainable Development.

Aribigbola, A. (2008). Improvong urban land use planning and management in Nigeria: the case of Akure. Theoretical and Empirical Researches in Urban Management, 3, 1-14.

Arowosegbe, J. O. (2016). Ethnic minorities and the land question in Nigeria. Review of African Political Economy.

Awotide, O. D. ., Kehinde, A. L. ., \& Agbola, P. O. . (2010). Poverty and rural livelihood diversification among farming households in southwest Nigeria. Journal of Food, Agriculture and Environment, 8, 367-371.

Awumbila, M., \& Ardayfio-Schandorf, E. (2008). Gendered poverty, migration and livelihood strategies of female porters in Accra, Ghana. Norsk Geografisk Tidsskrift - Norwegian Journal of Geography, 62, 171-179. 
Ayanniyi, A., Balarabe, A., \& Mahmoud, A. (2014). The Sokoto blind beggars: Causes of blindness and barriers to rehabilitation services. Middle East African Journal of Ophthalmology, 21(2), 147.

Barrett, C. B., Reardon, T., \& Webb, P. (2001). Nonfarm income diversification and household livelihood strategies in rural Africa: Concepts, dynamics, and policy implications. Food Policy, 26, 315-331.

Barry, M., \& Danso, E. K. (2014a). Tenure security, land registration and customary tenure in a peri-urban Accra community. Land Use Policy, 39, 358-365.

Barry, M., \& Danso, E. K. (2014b). Tenure security, land registration and customary tenure in a peri-urban Accra community. Land Use Policy, 39, 358-365.

Barthel, S., \& Isendahl, C. (2013). Urban gardens, Agriculture, And water management: Sources of resilience for long-term food security in cities. Ecological Economics, 86.

Battersby, J., Crush, J., Caesar, M., Tevera, D., Simelane, N., Riley, L., ... Visser, G. (2014). Household Food Insecurity and Survival in Harare: 2008 and Beyond. Urban Forum, (January), 1-12.

Bezemer, D., \& Headey, D. (2008). Agriculture, Development, and Urban Bias. World Development, 36, 1342-1364.

Bigsten, A. (1996). The circular migration of smallholders in Kenya. Journal of African Economies, 5, 1-20.

Bigsten, A., \& Moene, K. O. (1996). Growth and rent dissipation: The case of Kenya. Journal of African Economies, 5, 177-198.

Bowyer-Bower, T. a. S., \& Shiva, V. (1996). Staying Alive: Women, Ecology and Development. The Geographical Journal (Vol. 162).

Braimoh, A. K., \& Onishi, T. (2007). Spatial determinants of urban land use change in Lagos, Nigeria. Land Use Policy, 24, 502-515.

Brinkley, C. (2012). Evaluating the Benefits of Peri-Urban Agriculture. Journal of Planning Literature, 27(3), 259-269.

Brown-Luthango, M. (2011). Capturing Land Value Increment to Finance Infrastructure Investment-Possibilities for South Africa. Urban Forum, 22, 37-52.

Bruno Imokhai, O. Z. (2015). Effects of the 1978 Land Use Act on Sustainable Mining and Petroleum Industries in Nigeria. Arts and Social Sciences Journal.

Bryld, E. (2003). Potentials, problems, and policy implications for urban agriculture in developing countries. Agriculture and Human Values, 20(1), 79-86. 
Cabannes, Y. (2012). Financing urban agriculture. Environment and Urbanization.

Cabannes, Y., \& Raposo, I. (2013). Peri-urban agriculture, social inclusion of migrant population and Right to the City. City: Analysis of Urban Trends, Culture, Theory, Policy, Action, 17, 235-250.

Campbell, S. (1996). Green Cities, Growing Cities, Just Cities?: Urban Planning and the Contradictions of Sustainable Development. Journal of the American Planning Association, 62, 296-312.

Chen, M. A. (2007). Rethinking the Informal Economy: Linkages with the Formal Economy and the Formal Regulatory Environment, (46).

Chilowa, W. (1998). The impact of agricultural liberalisation on food security in Malawi. Food Policy, 23, 553-569.

Chuba, O., \& Eziyi, O. I. (2011). Securing urban land for housing among low - income earners in Sub - Saharan Africa : Case study of workers ' co - operative society, Enugu, Nigeria, 61-75.

Cofie, O., \& Awuah, E. (2008). Technology and institutional innovation on irrigated urban agriculture in Accra, Ghana. Urban Agriculture Magazine, (20), 14-16.

Cofie, O. O., Veenhuizen, R. Van, \& Drechsel, P. (2003a). Contribution of Urban and Peri-Urban Agriculture To Food Security in Sub-Saharan Africa. Water Management, 1-12.

Cofie, O. O., Veenhuizen, R. Van, \& Drechsel, P. (2003b). CONTRIBUTION OF URBAN AND PERI-URBAN AGRICULTURE TO FOOD SECURITY IN SUBSAHARAN AFRICA. Water Management, 1-12.

Crush, J., Frayne, B., \& Pendleton, W. (2012). The Crisis of Food Insecurity in African Cities. Journal of Hunger \& Environmental Nutrition.

De Zeeuw, H., Van Veenhuizen, R., \& Dubbeling, M. (2011). The role of urban agriculture in building resilient cities in developing countries.

Decker, S. (2008). Building up goodwill: British business, development and economic nationalism in Ghana and Nigeria, 1945-1977. Enterprise and Society.

Drechsel, P., Cofie, O., \& Danso, G. (2010). Closing the Rural-Urban Food and Nutrient Loops in West Africa : A reality check. Urban Agriculture, (23), 8-10.

Drechsel, P., \& Dongus, S. (2010). Dynamics and sustainability of urban agriculture: Examples from sub-Saharan Africa. Sustainability Science, 5, 69-78.

Drechsel, P., \& Evans, A. E. V. (2010). Wastewater use in irrigated agriculture. Irrigation and Drainage Systems, 24, 1-3. 
Dubbeling, M. (2011). Integrating urban agriculture in the urban landscape. Urban Agriculture Magazine, (25), 43-46.

Eapen, M. (2001). Rural non-farm employment: Agricultural versus urban linkages some evidence from Kerala state, India. Journal of Peasant Studies.

Ebeku, K. S. A. (2002). Oil and the Niger Delta people: the injustice of the Land Use Act. Verfassung Und Recht in Übersee.

Egbuna, N. E. (2010). UPA A STRATEGY FOR POVERTY REDUCTION IN NIGERIA. Eigenbrod, C., \& Gruda, N. (2015). Urban vegetable for food security in cities. A review. Agronomy for Sustainable Development.

Ellis, F. (1998). Household strategies and rural livelihood diversification. Journal of Development Studies.

Ellis, F. (2006). Agrarian change and rising vulnerability in rural sub-Saharan Africa. New Political Economy.

Ellis, F., \& Allison, E. (2001). Linking Livelihood Diversification to Natural Resources in a Poverty Reduction Context. LSP Briefing Notes.

Ellis, F., \& Mdoe, N. (2003). Livelihood and rural poverty reduction in Tanzania. World Development, 31, 1367-1384.

Ezedinma, C., \& Chukuezi, C. (1999). A comparative analysis of urban agricultural enterprises in Lagos and Port Harcourt, Nigeria. Environment and Urbanization, 11(2), 135-144.

Fabiyi, Y. L. (1984). Land administration in Nigeria: Case studies of the implementation of the land use decree (Act) in Ogun, Ondo and Oyo States of Nigeria. Agricultural Administration.

FAO. (2013). The state of food and agriculture.

Fonchingong, C. (1999). Structural adjustment, women, and agriculture in Cameroon. Gender and Development, 7, 73-79.

Fox, S., \& Goodfellow, T. (2016). Cities and development: Second edition. Cities and Development: Second Edition.

Frayne, B., McCordic, C., \& Shilomboleni, H. (2014). Growing Out of Poverty: Does Urban Agriculture Contribute to Household Food Security in Southern African Cities? Urban Forum, 1-13.

Gertler, M. S. (2010). Rules of the Game: The Place of Institutions in Regional Economic Change. Regional Studies.

Goldstein, B., Hauschild, M., Fernández, J., \& Birkved, M. (2016). Urban versus 
conventional agriculture, taxonomy of resource profiles: a review. Agronomy for Sustainable Development.

Government, N. (2007). Nigerian Constitution of 1999 Ammended, 1-183.

Gupta, R., \& Gangopadhyay, S. G. (2006). Peri-Urban Agriculture and Aquaculture. Economic and Political Weekly, 41(18), 1757-1760.

Guyer, J. I., \& Lambin, E. F. (1993). Land use in an urban hinterland: Ethnography and remote sensing in the study of African intensification. American Anthropologist, 95, 839-859.

Guyer, J. I., Lambin, E. F., Cliggett, L., Walker, P., Amanor, K., Bassett, T., ... Unruh, J. (2007). Temporal heterogeneity in the study of African land use: Interdisciplinary collaboration between anthropology, human geography and remote sensing. Human Ecology, 35, 3-17.

Halkias, D., Nwajiuba, C., Harkiolakis, N., \& Caracatsanis, S. M. (2011). Challenges facing women entrepreneurs in Nigeria. Management Research Review, 34(2),

Hart, K. (2008). African Studies: Informal Income Opportunities and Urban Employment in Ghana Informal Income Opportunities and Urban Employment in Ghana, (May 2014), 61-89.

Ikejiofor, U. (2006). Equity in informal land delivery: Insights from Enugu, Nigeria. Land Use Policy, 23, 448-459.

ILO. (2013). Labour Issues in Urban and Peri-Urban Agriculture: Information and Resource Guide.

Joachim, O. I., Kamarudin, N., \& Aliagha, G. U. (2015). Application of the powers of governors??? to charge ground rent under nigeria land use act of 1978. Jurnal Teknologi.

Knoblauch, J. (2012). Agriculture in urban planning; generating livelihoods and food security. Planning Perspectives.

Kuusaana, E. D., \& Eledi, J. A. (2015). As the city grows, where do the farmers go? Understanding Peri-urbanization and food systems in Ghana - Evidence from the Tamale Metropolis. Urban Forum, 26(4).

La Rosa, D., Barbarossa, L., Privitera, R., \& Martinico, F. (2014). Agriculture and the city: A method for sustainable planning of new forms of agriculture in urban contexts. Land Use Policy, 41, 290-303.

Land Use ACT. (1978). Nigerian Land Use Act 1978. Policy and Legal Advocacy Centre. 
Lee-Smith, D. (2010). Cities feeding people: an update on urban agriculture in equatorial Africa. Environment and Urbanization, 22, 483-499.

Lovell, S. T. (2010). Multifunctional Urban Agriculture for Sustainable Land Use Planning in the United States. Sustainability. https://doi.org/10.3390/su2082499 Lynch, K., Binns, T., \& Olofin, E. (2001). Urban agriculture under threat. Cities. Lynch, K., Maconachie, R., Binns, T., Tengbe, P., \& Bangura, K. (2013). Meeting the urban challenge? Urban agriculture and food security in post-conflict Freetown, Sierra Leone. Applied Geography, 36.

Mabogunye, A. (2010). Land reform in Nigeria: progress, problems \& prospects. Retrieved from World Bank:1-25.

Marx, C. (2006). Conceptualising ' the economy' to make urban land markets work for the poor, (November).

Mawois, M., Aubry, C., \& Le Bail, M. (2011). Can farmers extend their cultivation areas in urban agriculture? A contribution from agronomic analysis of market gardening systems around Mahajanga (Madagascar). Land Use Policy, 28, 434-445.

Maxwell, D. (1997). Adaptable livelihoods. Coping with food insecurity in the Malian Sahel. Food Policy.

Maxwell, D. (1999). The political economy of urban food security in Sub-Saharan Africa. World Development, 27(11), 1939-1953.

MAXWELL, D. M. A.-K. (2000). Urban Agriculture in Greater Accra: Reviewing Research Impacts for Livelihoods, Food and Nutrition Security, (September).

McDowell, C. . M. . (1970). The Interpretation of the Land Tenure Law of Northern Nigeria. Journal of African Law, 14(3), 155-177.

McLees, L. (2011). Access to land for urban farming in Dar es Salaam, Tanzania: histories, benefits and insecure tenure. The Journal of Modern African Studies.

McNicoll, K. (2011). Women Feeding Cities: Mainstreaming Gender in Urban Agriculture and Food Security. Development in Practice.

Meagher, K. (1995). Crisis, Informalization and the Urban Informal Sector in SubSaharan Africa. Development and Change, 26, 259-284.

Meagher, K. (2005). Social capital or analytical liability? Social networks and African informal economies. Global Networks.

Meagher, K. (2006). Social capital, social liabilities, and political capital: Social networks and informal manufacturing in Nigeria. African Affairs, 105, 553-582. Midmore, D. J., \& Jansen, H. G. P. (2003). Supplying vegetables to Asian cities: Is 
there a case for peri-urban production? Food Policy, 28(1), 13-27.

Mkwambisi, D. D., Fraser, E. D. G., \& Dougill, A. J. (2011). Urban agriculture and poverty reduction: Evaluating how food production in cities contributes to food security, employment and income in Malawi. Journal of International Development, 23, 181-203.

Mlozi, M. R. S. (1995). Child Labour in Urban Agriculture: The Case of Dar es Salaam, Tanzania. Children's Environments, 12(2), 197-208.

Mougeot, L. (2000). Urban agriculture: definitions, presence, potentials and risks. Growing Cities, Growing Foods: Urban Agriculture on the Policy Agenda, 1-42. Mougeot, L. J. A. (2006). Growing better cities: urban agriculture for sustainable development. Cities (Vol. 19).

Mougeot, L. J. M. (2000). CFP Repoprt 31 - Urban Agriculture: Definition, Presence,

Potential and Risks, Main Policy Challenge. In Growing cities growing food urban agriculture on the policy agenda (pp. 14-40).

Moustier, P., \& Danso, G. (2006). Local economic development and marketing of urban produced food. Cities Farming for the Future. Urban Agriculture for Sustainable Cities, 171-206.

Narayan, D., \& Pritchett, L. (1999). Cents and Sociability: Household Income and Social Capital in Rural Tanzania. Economic Development and Cultural Change. NBS, N. (2010). NIGERIA POVERTY PROFILE 2010.

Ngaido, T. (2004). Reforming land rights in Africa. In Assuring Food and Nutrition Security in Africa by 2020: Prioritizing Actions, Strengthening Actors, and Facilitating Partnerships," held in Kampala, Uganda,April 1-3, (p. 6).

Niehof, A. (2004). The significance of diversification for rural livelihood systems. Food Policy, 29, 321-338.

Nkurunziza, E. (2008). Understanding informal urban land access processes from a legal pluralist perspective: The case of Kampala, Uganda. Habitat International, 32(1), 109-120.

Nwagbara, E. Nn. (2011). THE STORY OF STRUCTURAL ADJUSTMENT PROGRAMME IN NIGERIA FROM THE PERSPECTIVE OF THE ORGANIZED LABOUR - Open Access Library. Australian Journal of Business and Management Research, 1(7), 30-41.

O'Higgins, N. (1997). The challenge of youth unemployment. International Social Security Review, 50, 63-93. 
Obeng-Odoom, F. (2013). The State of African Cities 2010: Governance, inequality and urban land markets. Cities, 31, 425-429.

Oladapo Sam, I. (2014). Achieving Sustainable Poverty Reduction and Rural Development in Nigeria through Local Economic Development Strategies. American Journal of Rural Development.

Orsini, F., Kahane, R., Nono-Womdim, R., \& Gianquinto, G. (2013). Urban agriculture in the developing world: A review. Agronomy for Sustainable Development.

Ostrom, E. (2000). Private and Common Property Rights. In Encyclopedia of Law and Economics (Vol. 2, pp. 332-379).

Otsuka, K., Quisumbing, A. R., Payongayong, E., \& Aidoo, J. B. (2003). Land tenure and the management of land and trees: the case of customary land tenure areas of Ghana. Environment and Development Economics.

Oumer, A. M., \& de Neergaard, A. (2011). Understanding livelihood strategy-poverty links: Empirical evidence from central highlands of Ethiopia. Environment, Development and Sustainability, 13, 547-564.

Pearson, L. J., Pearson, L., \& Pearson, C. J. (2010). Sustainable urban agriculture: stocktake and opportunities. International Journal of Agricultural Sustainability.

Rakodi, C. (2003). Politics and performance: The implications of emerging governance arrangements for urban management approaches and information systems. Habitat International, 27, 523-547.

Ravallion, M., \& Lipton, M. (2005). POVERTY and POLICY.

Roy, A. (2005). Urban Informality: Toward an Epistemology of Planning. Journal of the American Planning Association.

Sathuraman, S. V. (1976). 114 International Labour Review 1976 Urban Informal Sector: Concept, Measurement and Policy.

Scott, C. A., Drechsel, P., Raschid-sally, L., Bahri, A., Mara, D., Redwood, M., \& Jiménez, B. (2010). Wastewater Irrigation and Health: Challenges and Outlook for Mitigating Risks in Low-Income Countries. In Wastewater irrigation and health: assessing and mitigating risk in low-income countries (pp. 381-394).

Shillington, L. J. (2013). Right to food, right to the city: Household urban agriculture, and socionatural metabolism in Managua, Nicaragua. Geoforum, 44, 103-111.

Shimada, S. (1999). A Study of Increased Food Production in Nigeria: The Effect of the Structural Adjustment Program on the Local Level. African Study Monographs, 20, 175-227. 
Smit, J., \& Nasr, J. (1992). Urban agriculture for sustainable cities: using wastes and Steel, C. (2008). Hungry City: How Food Shapes Our Lives. Random House Group $L t d$.

Steward, A. (2007). Nobody farms here anymore: Livelihood diversification in the Amazonian community of Carv??o, a historical perspective. Agriculture and Human Values, 24, 75-92.

Taiwo, O. J. (2013). Farmers' choice of wetland agriculture: Checking wetland loss and degradation in Lagos State, Nigeria. GeoJournal, 78(1), 103-115.

Taiwo, O. J. (2014). Determinants of peri-urban and urban agricultural locational choice behaviour in Lagos, Nigeria. Land Use Policy, 39, 320-330.

Tambwe, N., Rudolph, M., \& Greenstein, R. (2011). "INSTEAD OF BEGGING, I FARM TO FEED MY CHILDREN": URBAN AGRICULTURE - AN ALTERNATIVE TO COPPER AND COBALT IN LUBUMBASHI. Africa: Journal of the International African Institute, 81(3), 391-412.

Tanner, T. M., \& Mitchell, T. (2009). Introduction: Building the Case for Pro-Poor Adaptation. IDS Bulletin, 39, 1-5.

Tevera, D., \& Simelane, N. (2014). Food for the Urban Poor: Safety Nets and FoodBased Social Protection in Manzini, Swaziland. Urban Forum, 1-12.

Umukoro, N. (2012). Governance and environmental inequality in Nigeria: Implications for conflict management strategies in the Niger Delta. International Journal of Environmental Studies.

USAID. (2013). Property Rights and Resource Governance, 1-40.

Vagneron, I. (2007). Economic appraisal of profitability and sustainability of peri-urban agriculture in Bangkok. Ecological Economics, 61(2-3), 516-529.

Veenhuizen, R. van., \& Danso, G. (2007). Profitability and sustainability of urban and peri-urban agriculture. Finance, 95.

Veenhuizen, R. van. (2006). Cities Farming for the Future - Urban Agriculture for Green and Productive Cities (2006). In R. van Veenhuizen (Ed.), Cities Farming for the Future - Urban Agriculture for Green and Productive Cities (2006) (pp. 117). RUAF Foundation, IDRC and IIRR.

Viljoen, A., \& Bohn, K. (2012). Scarcity and abundance: Urban agriculture in Cuba and the US. Architectural Design, 82, 16-21.

Ward, C. D., \& Shackleton, C. M. (2016). Natural Resource Use, Incomes, and Poverty Along the Rural-Urban Continuum of Two Medium-Sized, South African Towns. 
World Development, 78, 80-93.

Warshawsky, D. N. (2016). Civil society and public-private partnerships: case study of the Agri-FoodBank in South Africa. Social and Cultural Geography, 17(3), 423443.

White, P. (1986). Land availability, land banking and the price of land for housing: A review of recent debates. Land Development Studies.

Whittinghill, L. J., \& Rowe, D. B. (2012). The role of green roof technology in urban agriculture. Renewable Agriculture and Food Systems.

WIEGO. (2010). Decent Work for Domestic Workers: International Labour Conference,.

Wilson, D., Velis, C., \& Cheeseman, C. (2006). Role of informal sector recycling in waste management in developing countries. Habitat International, 30, 797-808.

Zasada, I. (2011). Multifunctional peri-urban agriculture-A review of societal demands and the provision of goods and services by farming. Land Use Policy. 